\title{
Detection Methods of Fungi in Ilex paraguariensis Seeds
}

\author{
Gabriela Fernanda Souza ${ }^{1}$ (1) 0000-0002-1875-9950 \\ Luciana Magda de Oliveira ${ }^{1}$ (1) 0000-0001-7362-1041 \\ Ricardo Trezzi Casa ${ }^{1}$ (D) 0000-0003-3563-8525 \\ Lenita Agostinetto ${ }^{2}$ (1) 0000-0002-0468-883X \\ Anieli Cioato de Souza ${ }^{1}$ (1) 0000-0001-5989-5740
}

\begin{abstract}
There has been an increase in the occurrence of fungal diseases in Ilex paraguariensis A. St.-Hill. (yerba mate) resulting from their domestication. Seed health tests may indicate pathogens prior to sowing, enabling their control. Our study sought to compare the efficacy of fungi detection methods on yerba mate seeds. Seeds from four lots were subjected to the following detection methods: BDA, V8 and filter paper; as well as the performance of asepsis with $1 \%$ sodium hypochlorite and $70 \%$ alcohol. The fungi found in the lots were: Penicillium spp., Cladosporium spp., Aureobasidium melanogenum, Aspergillus spp., Pestalotia spp., Nigrospora spp., Trichoderma spp., Fusarium graminearum, F. oxysporum and F. guttiforme. The asepsis in the seeds reduced the occurrence of contaminating organisms. There were differences between the evaluated lots regarding fungal incidence. In general, the BDA and V8 culture media showed better results in fungal detection.
\end{abstract}

Keywords: seed pathology, yerba-mate, sanity tests.

\section{INTRODUCTION AND OBJECTIVES}

Ilex paraguariensis A. St. Hill (Aquifoliaceae), known as yerba mate, is a characteristic species of Mixed Ombrophilous Montana Forest, associated with Araucaria angustifolia and found in some regions belonging to Semi-deciduous Seasonal Forest (Carvalho, 2003; Mazuchowski, 1989).

Yerba mate integrates one of the main Brazilian agroforestry systems, contributing to income generation for small and medium farmers in Southern Brazil (Sturion \& Resende, 2010). Its use in the area of pharmaceuticals comprises a potential market and alternative to its commercialization as a beverage, in which it is widely used for preparing teas and chimarrão (Maccari, 2005; Sturion \& Resende, 2010).

There have been great advances related to genetic improvement and management of yerba mate recently, with the main focus on increasing the productivity of herbs (Grigoletti \& Auer, 2005). However, the occurrence of diseases in the crop has grown considerably due to its domestication, the increase in its planted area and the implemented management practices.
The most serious problems are registered in seedling nurseries of the species, favoring the development of pathogens due to the humidity conditions and high plant density (Grigoletti \& Auer, 2005).

A potential source of disease-causing pathogens are the contaminated seeds used for seedling production due to the protection and nutrients they provide to micro-organisms (Machado, 2012).

One of the main genera of fungi considered as pathogenic to forest seeds is Fusarium, which can colonize fruits, branches, leaves and inflorescences (Poletto et al., 2006). This genus causes root rot in yerba mate, which can cause the death of plants and constituting a growing problem in the southern region of Brazil (Poletto et al., 2006; Poletto et al., 2010).

The filter paper method is one of the most used for fungi detection, characterized as an easy-to-conduct and low cost method. It enables the identification and quantification of the main fungi and can be used for all the seeds (Parisi \& Santos, 2015).

When the filter paper method does not provide suitable conditions for the growth and sporulation of certain fungal

\footnotetext{
${ }^{1}$ Universidade do Estado de Santa Catarina (Udesc), Lages, SC, Brasil

${ }^{2}$ Universidade do Planalto Catarinense (Uniplac), Lages, SC, Brasil
} 
groups, agaric media containing solutions and nutrients essential for their growth and reproduction are used, such as potato dextrose agar (BDA), known as universal culture medium (Henning, 2004; Zauza et al., 2007).

Thus, our study sought to compare the efficacy of different fungus detection methods on yerba mate seeds.

\section{MATERIALS AND METHODS}

The yerba mate seeds were harvested at four locations with distinct characteristics (Table 1). The seeds were harvested from several matrices at least 50 meters apart at each harvest location. The harvests were performed by means of fabric screens placed below the treetops. Fruits with dark purple coloring were considered mature, classified as color 2.5/1 F: 5Y on the Munsell Soils Table (2009), which consists of a color notebook initially used for characterizing soils. The seeds were extracted in a sieve and running water, and manually sorted to remove the impurities.

Determination of the moisture content of the seeds was carried out in a greenhouse with forced air circulation, regulated at $105 \pm 3^{\circ} \mathrm{C}$ for 24 hours. The results were expressed as a percentage based on the wet weight of the seeds, according to the Rules for Seed Analysis (Brasil, 2009).

Three methods of detecting pathogens in the seeds were tested: 1) BDA culture medium (200 grams of potato extract +20 grams of dextrose +20 grams of agar $/ \mathrm{L})+0.02$ grams of streptomycin; 2) diluted V8 culture medium ( $40 \mathrm{ml}$ of V8 juice - vegetable juice "Campbell Soup Co" +0.6 grams of $\mathrm{CaCO}_{3}+20$ grams of agar +1.0 grams of sucrose +0.2 grams of yeast extract +0.1 grams of neomycin sulfate +0.02 grams of chlorofenicol $+1 \mathrm{~L}$ of distilled water); and 3) filter paper.

To prepare the BDA culture medium, 200 grams of peeled potatoes were boiled in $500 \mathrm{ml}$ of water for at least 30 minutes, then the broth was filtered with the aid of gauze. The molten agar together with the dextrose was added to $500 \mathrm{ml}$ of water, and the broth from cooking the potatoes was then added. The volume was then filled with $1,000 \mathrm{~mL}$ with distilled water and autoclaving at $120^{\circ} \mathrm{C}$ for 20 minutes and adding $0.02 \mathrm{~g}$ antibiotic Streptomycin (Zauza et al., 2007). For preparing the V8 culture medium, the molten agar was added to the other components (V8 juice, $\mathrm{CaCO}_{3}$, sucrose, yeast extract and distilled water), completing the volume of $1,000 \mathrm{~mL}$ and autoclaving at $120^{\circ} \mathrm{C}$ for 20 minutes (Zauza et al., 2007).

For the filter paper method, two sheets of paper were autoclaved at $1 \mathrm{~atm}\left(120^{\circ} \mathrm{C}\right)$ for 20 minutes and then moistened with distilled and sterilized water, also autoclaved at $1 \mathrm{~atm}$ $\left(120^{\circ}\right)$ for 20 minutes.

Two hundred seeds of each lot and method (V8, BDA and Filter Paper) were divided into four replicates of 50 seeds. Each replicate was composed of four Petri dishes, disinfected in $1 \%$ sodium hypochlorite for 30 seconds and alcohol $70 \%$ before plating, then washed three times in sterile distilled water to remove the sodium hypochlorite residue. Subsequently, the seeds were put to dry on filter paper and then packaged in Petri dishes containing the different evaluated methods.

Another 200 seeds per lot and method were subjected to sanitary tests on agar medium and filter paper without asepsis. Four replicates of 50 seeds were used per lot for each method. Incubation was performed in a BOD (Biochemical Oxygen Demand) type growth chamber at a temperature of $22 \pm 3{ }^{\circ} \mathrm{C}$, with 12 hours of photoperiod.

The experimental design was completely randomized with four replicates for each performed test. The data arrangement of the seed health evaluation experiment was bifactorial composed of $4 \times 3$ replicates (four provenances $\times$ three methods of detection).

The fungi were evaluated by observing their reproductive structure under a stereoscopic and optical microscope, and the identification was performed with the aid of the identification key (Barnett \& Hunter, 1972). Fungus incidence data were expressed as a percentage.

Identification for the Fusarium and Aureobasidium genera was conducted molecularly by the Biological Institute through isolates of all the origins in which they had incidence. Fusarium guttiforme, Fusarium oxysporum and Aureobasidium melanogenum were identified by the TEF region (Translation Elongation Factor) for Fusarium guttiforme, and ITS (Internal Transcribed Spacer, not deposited in GenBank) for the others.

Table 1. Seed collection locations of Ilex paraguariensis for sanity tests with different detection methods.

\begin{tabular}{|c|c|c|c|c|}
\hline Lot & Altitude (m) & Average rainfall (mm/year) & $\begin{array}{l}\text { Average rainfall during } \\
\text { seed production }(\mathrm{mm})^{1}\end{array}$ & Average temperature $\left({ }^{\circ} \mathrm{C}\right)$ \\
\hline Urupema - SC & 1.324 & 1634 & 145.0 & 14.1 \\
\hline Porto União - SC & 780 & 1667 & 161.25 & 17.7 \\
\hline Ajuricaba - RS & 331 & 1768 & 153.75 & 19.8 \\
\hline Campo-Erê - SC & 903 & 2045 & 180.5 & 16.7 \\
\hline
\end{tabular}

${ }^{1}$ Period of seed production: October to December.

Source: Climate (2018). 
The percentage data for the analysis of variance were transformed by the formula: Arcsen [( $x+0.5) /(100)] 1 / 2$. The comparison of means was performed by the Tukey's test at $5 \%$ probability, while the SISVAR program was used for the statistical analysis.

\section{RESULTS AND DISCUSSION}

The asepsis decreased the incidence of contaminating microorganisms for all seed lots such as Rhizopus spp. and bacteria (Figure 1). These contaminants grow rapidly and interfere with the correct identification of pathogenic fungi.

High infestation of plaques with Rhizopus spp. was observed for all lots without asepsis, especially for the BDA method (Figure 2). The highest occurrence of infestation on
BDA plaques can be explained by the high concentration of carbon available to the fungi through the starch from potatoes present in the medium. Thus, we decided to only work with disinfected seeds based on these results.

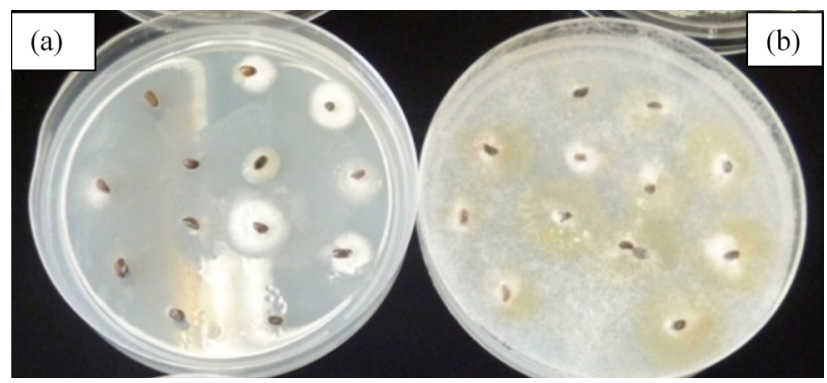

Figure 1. Incidence of contaminating fungi in yerba mate seeds with asepsis (a) and without asepsis (b).

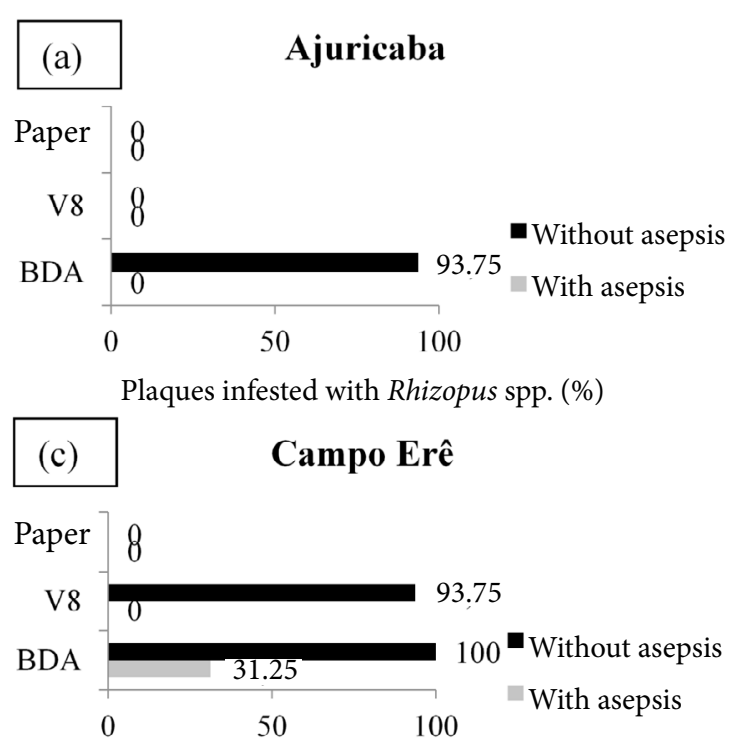

Plaques infested with Rhizopus spp. (\%)
Porto União

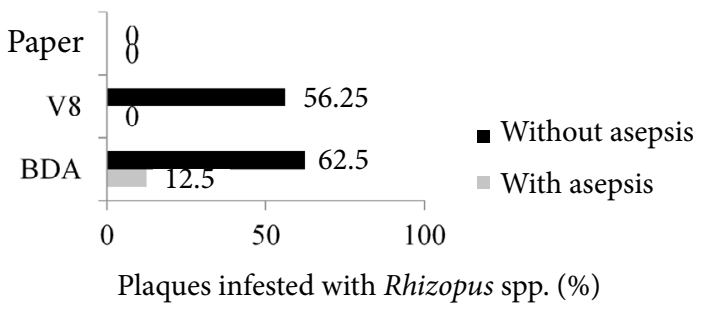

Urupema

(d)

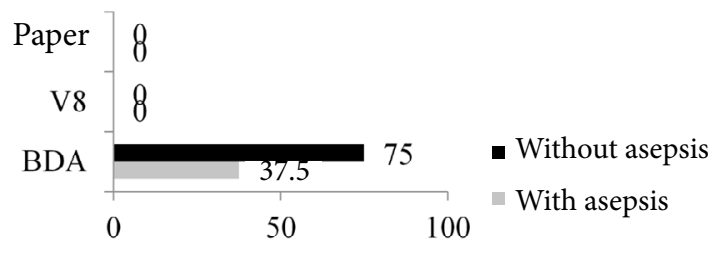

Plaques infested with Rhizopus spp. (\%)

Figure 2. Percentage of plaques infested with Rhizopus spp. during sanity test of yerba mate seeds.

Regarding the fungal incidence, the following fungi were identified in yerba mate seeds: Penicillium spp. (identified morphologically), Fusarium graminearum (identified morphologically), F. oxysporum (molecularly identified by ITS region sequencing-Internal Transcribed Spacer), F. guttiform (molecularly identified by TEF region sequencing - Internal Transcribed Spacer), Cladosporium spp. (identified morphologically), Aureobasidium melanogenum (molecularly identified by ITS region sequencing - Internal Transcribed Spacer) and Aspergillus spp. (morphologically identified). Nigrospora spp., Bipolaris spp., Alternaria spp. and Trichoderma spp. (all identified morphologically). These fungi were observed in lower incidence (Table 2).

The Polymerization Chain Reaction (PCR) technique has been used in several research areas, including fungi identification. One of the main regions used to identify pathogens is Internal Transcribed Spacer (ITS), located in the ribosomal DNA, with genetic variation that enables identifying pathogens (Jaccoud-Filho \& Dabul, 2015). 
Table 2. Incidence of fungi (\%) in yerba mate seeds from four places, subjected to the sanity test on agar media and filter paper.

\begin{tabular}{|c|c|c|c|c|c|}
\hline \multirow{2}{*}{ Fungus } & \multirow{2}{*}{ Location } & \multicolumn{3}{|c|}{ Substrate } & \multirow[b]{2}{*}{ Average } \\
\hline & & BDA & V8 & Paper & \\
\hline \multirow{4}{*}{ Fusarium oxysporum } & Porto União & $12.5 \mathrm{bB}^{1}$ & $3.0 \mathrm{abA}$ & $0.0 \mathrm{aA}$ & 5.2 \\
\hline & Campo Erê & $22.5 \mathrm{cC}$ & $9.5 \mathrm{Bb}$ & $0.0 \mathrm{aA}$ & 10.5 \\
\hline & Ajuricaba & $0.0 \mathrm{aA}$ & $0.0 \mathrm{aA}$ & $0.0 \mathrm{aA}$ & 0.0 \\
\hline & Urupema & $12.0 \mathrm{bB}$ & $10.0 \mathrm{bB}$ & $0.0 \mathrm{aA}$ & 7.3 \\
\hline Average & & 11.7 & 5.6 & 0.0 & CV(\%): 29.7 \\
\hline \multirow{4}{*}{$\begin{array}{l}\text { Fusarium } \\
\text { graminearum }\end{array}$} & Porto União & $33.5 \mathrm{cB}$ & $47.5 \mathrm{cC}$ & $0.5 \mathrm{aA}$ & 27.2 \\
\hline & Campo Erê & $0.0 \mathrm{aA}$ & $0.0 \mathrm{aA}$ & $1.5 \mathrm{aA}$ & 0.5 \\
\hline & Ajuricaba & $0.0 \mathrm{aA}$ & $0.0 \mathrm{aA}$ & $0.0 \mathrm{aA}$ & 0.0 \\
\hline & Urupema & $9.0 \mathrm{bA}$ & $12.0 \mathrm{bA}$ & $10.0 \mathrm{bA}$ & 10.3 \\
\hline Average & & 10.6 & 14.8 & 3.0 & $\mathrm{CV}(\%): 27.8$ \\
\hline \multirow{4}{*}{ Fusarium guttiforme } & Porto União & $22.0 \mathrm{bB}$ & $32.5 \mathrm{bC}$ & $16.0 \mathrm{bA}$ & 23.5 \\
\hline & Campo Erê & $30.5 \mathrm{bB}$ & $46.5 \mathrm{cC}$ & $13.0 \mathrm{abA}$ & 30.0 \\
\hline & Ajuricaba & $2.0 \mathrm{aA}$ & $0.0 \mathrm{aA}$ & $0.0 \mathrm{aA}$ & 0.7 \\
\hline & Urupema & $27.0 \mathrm{bB}$ & $32.5 \mathrm{bB}$ & $5.0 \mathrm{abA}$ & 21.5 \\
\hline Average & & 20.4 & 27.9 & 8.5 & $\mathrm{CV}(\%): 21.3$ \\
\hline \multirow{4}{*}{ Penicillium spp. } & Porto União & $1.0 \mathrm{aA}$ & $0.0 \mathrm{aA}$ & $3.5 \mathrm{aA}$ & 1.5 \\
\hline & Campo Erê & $9.0 \mathrm{bB}$ & $0.0 \mathrm{aA}$ & $1.5 \mathrm{aA}$ & 3.5 \\
\hline & Ajuricaba & $1.5 \mathrm{aA}$ & $0.0 \mathrm{aA}$ & $0.0 \mathrm{aA}$ & 0.5 \\
\hline & Urupema & $2.5 \mathrm{aAB}$ & $5.0 \mathrm{bB}$ & $0.0 \mathrm{aA}$ & 4.2 \\
\hline Average & & 3.5 & 1.3 & 1.3 & CV(\%): 49.8 \\
\hline \multirow{4}{*}{ Aspergillus spp. } & Porto União & $1.5 \mathrm{aA}$ & $0.0 \mathrm{aA}$ & $2.5 \mathrm{aA}$ & 1.3 \\
\hline & Campo Erê & $1.5 \mathrm{aA}$ & $44.5 \mathrm{bB}$ & $1.0 \mathrm{aA}$ & 15.6 \\
\hline & Ajuricaba & $0.0 \mathrm{aA}$ & $0.0 \mathrm{aA}$ & $0.5 \mathrm{aA}$ & 0.0 \\
\hline & Urupema & $0.0 \mathrm{aA}$ & $0.0 \mathrm{aA}$ & $0.0 \mathrm{aA}$ & 0.0 \\
\hline Average & & 0.8 & 11.1 & 1.0 & CV(\%): 91.5 \\
\hline \multirow{4}{*}{ Cladosporium spp. } & Porto União & $0.0^{1} \mathrm{aA}$ & $2.5 \mathrm{aA}$ & $0.0 \mathrm{aA}$ & 0.8 \\
\hline & Campo Erê & $0.0 \mathrm{aA}$ & $0.0 \mathrm{aA}$ & $0.0 \mathrm{aA}$ & 0.0 \\
\hline & Ajuricaba & $0.0 \mathrm{aA}$ & $0.0 \mathrm{aA}$ & $0.0 \mathrm{aA}$ & 0.0 \\
\hline & Urupema & $4.5 \mathrm{aA}$ & $17.0 \mathrm{bB}$ & $0.0 \mathrm{aA}$ & 7.2 \\
\hline Average & & 1.1 & 4.8 & 0.0 & CV(\%): 91.5 \\
\hline
\end{tabular}

${ }^{1}$ Equivalent lowercase letters in the column and upper case in the row do not differ statistically from each other by the Tukey's test with $5 \%$ probability.

Poletto et al. (2015) observed the incidence of fungi genera Verticillium, Penicillium, Paecilomyces, Phoma, Trichoderma, Alternaria, Cladosporium, Epicoccum, Mucor, Dactylella, Oidiodendron and Rhizopus in yerba mate seeds sorted by nursery workers from different locations in Rio Grande do Sul. In evaluating lots of yerba mate seeds from Rio Grande do Sul and Santa Catarina, Oliveira et al. (2015) indicated the incidence of Penicillium, Rhizoctonia, Fusarium, Trichoderma, Alternaria and Phomopsis detected by the filter paper method and BDA culture medium. In addition to pathogenic fungi, the identification of rotting fungi such as Penicillium is of great importance for maintaining seed quality.

In general, the Campo Erê lot presented the highest fungal incidence among the evaluated lots, except for F. graminearum, which had a higher incidence for the Porto União lot, Penicillium spp. and Cladosporium spp., which had the highest incidence in the Urupema lot. The Ajuricaba lot presented the lowest incidence for all identified fungi (Table 2).

According to Marcos Filho (2015), the association of seeds with pathogens mainly occurs during the maturation process. Thus, the climatic conditions in this period can 
significantly affect the sanity of seeds, favoring or hindering the survival and development of fungi.

For Bedendo (2011), factors such as humidity, temperature, light and wind may be responsible for the predisposition of plants to the attack of pathogens. Therefore, the results found in our study may be related to the occurrence of rainfall during the seed production period (from October to December); moreover, the Ajuricaba lot presented one of the lowest rainfall averages during the seed production period, while, in contrast, the Campo Erê lot presented the highest values of this climatic variable among the studied locations (Table 1).

Another factor that may influence seed health is the management performed on the matrices, such as distance from matrices with other individuals, fertilization and sanity. Thus, matrices with adequate distances between them with correct fertilization for their needs and which have sanitary control tend to produce seeds with better sanitary conditions. Poletto (2008) mentioned that infection of seeds by the Fusarium genus in most cultivated grains is favored by the supply of nitrogen to the plants. However, these relationships are determined by the form and content of nitrogen available, in addition to the vegetable/plant species.

In the detection methods, BDA showed greater efficiency in identifying Fusarium oxysporum and Penicillium spp. The V8 medium showed greater sensitivity in the detection of Fusarium graminearum, Fusarium guttiforme, Aspergillus spp. and Cladosporium spp. On the other hand, the filter paper method was considered the least efficient in detecting fungi identified in our study (Table 2). This is because the agar media are rich in nutrients, mainly carbon and nitrogen, favoring the development of microorganisms (Lazarotto et al., 2012; Zauza et al., 2007).

Rego (2005) considers that the filter paper method presents limitations for the detection of slow-growing and internally located fungi due to the absence of these nutrients in their composition. Oliveira et al. (2015) reported that BDA culture medium as well as the filter paper method are efficient in identifying fungi in yerba mate. Lazarotto et al. (2012) also found satisfactory results in detecting fungi using BDA as well as filter paper for Cedrela fissilis seeds. Fantinel et al. (2015) found that agar medium was more effective in detecting fungi in Acca sellowiana seeds.

The Fusarium genus, which presented considerable incidences in our study, is one of the main fungi associated with the tipping of yerba mate seedlings registered in the pre or post-emergence phase of the seedlings. Another problem that can be caused by the genus is root rot, which occurs in both sowing and seedlings, with yellowing and falling leaves, evolving to death of the branches and total drought in the plants (Grigoletti \& Auer, 1996).

Poletto et al. (2006) concluded that five species of Fusarium (F. oxysporum, F. solani, F. decemcellulare, F. tricinctum and F. tabacinum) are pathogenic and associated with root rot in yerba mate and may present different degrees of severity. Also, according to Grigoletti et al. (1998), the Colletotrichum, Fusarium and Rhizoctonia genera are potentially pathogenic to yerba mate.

The incidence of rotting fungi such as Penicillium spp., Aspergillus spp. and Cladosporium spp. were considered low for all evaluated seed lots. This fact can be explained by the moisture content of the seeds, which were from 6.93 to $12.52 \%$ (Table 3). According to Berjak (1995), these fungal genera have their proliferation and metabolic activity favored with humidity levels between 12 and 16\%. Marcos-Filho (2015) reports that the development of microorganisms occurs when the water content of the seeds is above $20 \%$, under relative humidity higher than $95 \%$.

Aspergillus spp. and Penicillium spp. are storage fungi, as their occurrence increases in the post-harvest period. They can cause physicochemical changes in the tissues of the seeds, causing loss of lipids, carbohydrates, proteins and increased fatty acid (Kruppa \& Russomanno, 2011; Lazarotto et al., 2010).

According to Cherobini et al. (2008), these fungal groups may cause seed rot and germination reduction in several forest species, in addition to Penicillium, and cause lesions in seedlings, decreasing their development. The results of Aureobasidium melanogenum were compared considering the two asepsis situations, seeking to illustrate their predominance in seeds from Ajuricaba, especially for the agar medium (Table 4 ).

The A. melanogenum species is an ascomycete belonging to the Dothioraceae family, presenting smooth, fast-growing colonies with viscous masses of conidia (asexual spores) that initially have a light color and are brown or black in color (Figure 3). The hyphae of this fungus are hyaline and septate, and the conidia are also of hyaline staining with smooth walls, ellipsoidal of variable sizes (Russel et al., 2016).

Table 3. Degree of moisture of yerba mate seeds from four harvesting locations.

\begin{tabular}{|cc|}
\hline Lot & Degree of moisture (\%) \\
\hline Porto União - SC & 6.93 \\
\hline Campo Erê - SC & 8.73 \\
\hline Ajuricaba - RS & 9.78 \\
\hline Urupema - SC & 12.52 \\
\hline
\end{tabular}


Table 4. Incidence (\%) of Aureobasidium melanogenum in yerba mate seeds from four collection locations with and without asepsis, and subjected to the sanity test on agar medium and filter paper.

\begin{tabular}{|c|c|c|c|c|c|c|c|c|c|}
\hline \multirow{2}{*}{ Fungi } & \multirow{2}{*}{ Location } & \multicolumn{4}{|c|}{ With asepsis } & \multicolumn{3}{|c|}{ Without asepsis } & \multirow{2}{*}{ Average } \\
\hline & & BDA & V8 & Paper & Average & BDA & V8 & Paper & \\
\hline \multirow{4}{*}{$\begin{array}{l}\text { Aureobasidium } \\
\text { melanogenum }\end{array}$} & Porto União & $0.0 \mathrm{aA}$ & $4.0 \mathrm{bB}$ & $0.0 \mathrm{aA}$ & 1.3 & $0.0 \mathrm{aA}$ & $3.0 \mathrm{aA}$ & $0.0 \mathrm{aA}$ & 1.0 \\
\hline & Campo Erê & $0.0 \mathrm{Aa}$ & $0.0 \mathrm{aA}$ & $0.0 \mathrm{aA}$ & 0.0 & $0.0 \mathrm{aA}$ & $0.0 \mathrm{aA}$ & $0.0 \mathrm{aA}$ & 0.0 \\
\hline & Ajuricaba & $1.5 \mathrm{Aab}$ & $0.0 \mathrm{aA}$ & $4.0 \mathrm{bB}$ & 0.5 & $66.0 \mathrm{bC}$ & $35.5 \mathrm{bB}$ & $5.5 \mathrm{bA}$ & 35.6 \\
\hline & Urupema & $0.0 \mathrm{Aa}$ & $0.0 \mathrm{aA}$ & $0.0 \mathrm{aA}$ & 0.0 & $0.0 \mathrm{Aa}$ & $0.0 \mathrm{aA}$ & $0.0 \mathrm{Aa}$ & 0.0 \\
\hline \multicolumn{2}{|l|}{ Average } & 0.37 & 1.0 & 1.0 & & 16.5 & 9.6 & 1.37 & \\
\hline \multicolumn{2}{|l|}{$\mathrm{CV} \%$} & & 46.23 & & & \multicolumn{4}{|c|}{120.79} \\
\hline
\end{tabular}

${ }^{1}$ Equivalent lowercase letters in the column and upper case in the row do not differ statistically from each other by the Tukey's test with $5 \%$ probability.

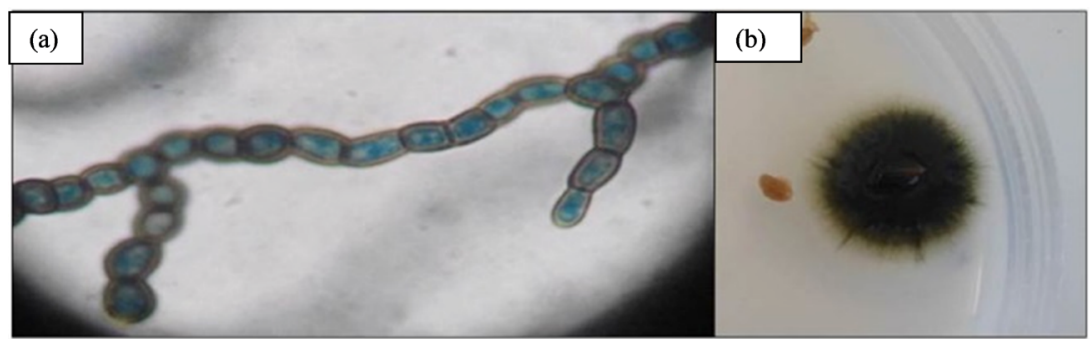

Figure 3. Characteristics of Aureobasidium melanogenum: (a) hyaline and septate hyphae; (b) colony in BDA medium.

Albiero et al. (2015) indicated Aureobasidium pullulans as one of the main yeasts found in leaves of I. paraguariensis from Vargeão, SC. Although reported as saprophytic and poorly pathogenic, the same species was considered pathogenic for mangaba (Harconia speciosa) (Anjos et al., 2009).

We emphasize the need for future studies seeking to evaluate the pathogenicity of A. melanogenum in Ilex paraguariensis seeds due to the little information found in the literature regarding the action of this fungi on forest seeds.

\section{CONCLUSION}

(i) The asepsis considerably reduces the occurrence of contaminants in sanity tests of yerba mate seeds;

(ii) There are differences between the evaluated lots of yerba mate seeds regarding the fungal incidence;

(iii) The detection methods in BDA and V8 culture medium showed higher efficiency in fungi detection associated with yerba mate seeds.

\section{ACKNOWLEDGEMENTS}

The authors thank the Fundação de Amparo à Pesquisa e Inovação do Estado de Santa Catarina (Fapesc).

\section{SUBMISSION STATUS}

Received: 2 Oct. 2017

Accepted: 13 Dec. 2018

Associate editor: Juliana Müller Freire

(D) 0000-0002-4758-2533

\section{CORRESPONDENCE TO}

\section{Gabriela Fernanda Souza}

Universidade do Estado de Santa Catarina (Udesc), Av. Luis de Camões, 2.090, CEP 88520-000, Lages, SC, Brasil e-mail: gabisouza93@hotmail.com

\section{FINANCIAL SUPPORT}

Fundação de Amparo à Pesquisa e Inovação do Estado de Santa Catarina (Fapesc).

\section{REFERENCES}

Albiero G, Silva PV, Costa M. Sanitary quality and diversity of culturable bacteria and yeasts in processed and in natura yerba mate (Ilex paraguariensis A. St.-Hil.). Revista Brasileira de Biociências 2015; 13(2): 90-95.

Anjos JRB, Charchar MJD, Leite RG, Silva MS. Levantamento e patogenicidade de fungos associados às sementes de mangaba (Hancornia speciosa Gomes) no cerrado do Brasil Central. Revista Brasileira de Fruticultura 2009; 31(3): 911-915. 
Barnett HL, Hunter BB. Illustred genera of imperfect fungi. 3rd ed. Minnesota: Burgess Publishing Company; 1972.

Bedendo IP. Ambiente e doença. In: Bergamin Filho A, Kimati H, Amorim L. Manual de Fitopatologia: princípios e conceitos. 4th ed. v. 1. São Paulo: Ceres; 2011.

Berjak P. The role of microorganisms in deterioration during storage of recalcitrant and intermediate seeds. In: Ouédr K, Stubsgaard F. Intermediate/recalcitrant tropical forest tree seeds: proceedings of a working on improved methods for handling and storage of intermediate/recalcitrant tropical forest tree seeds. Rome: IPGRI; 1995. p. 121-126.

Brasil. Ministério da Agricultura, Pecuária e Abastecimento. Manual de Análise Sanitária de Sementes. Brasília: Mapa/ACS; 2009.

Carvalho PER. Espécies Arbóreas Brasileiras. v. 1. Brasília: Embrapa; 2003.

Cherobini EAI, Muniz MFB, Blume E. Avaliação da qualidade de sementes e mudas de cedro. Ciência Florestal 2008; 18(1): 65-73.

Climate. Dados climáticos para cidades mundiais [Internet]. 2018 [cited 2016 Sept. 9]. Available from: https://bit.ly/2SSD2Of

Fantinel VS, Oliveira LM, Casa RT, Rocha EC, Scheneider PF, Vicente D. Tratamento de sementes de goiaba-serrana (Acca selowiana): efeito na incidência de fungos e na germinação. Revista Brasileira de Biociências 2015; 13(2): 84-89.

Grigoletti A Jr, Auer CG. Doenças da erva-mate: identificação e controle. Colombo: Embrapa; 1996.

Grigoletti A Jr, Auer CG. Doenças de Erva-Mate. In: Kimati H, Amorim L, Rezende JAM, Bergamin Filho A, Camargo LEA. Manual de Fitopatologia: doenças das plantas cultivadas. 4th ed. v. 2. São Paulo: Editora Agronômica Ceres; 2005. p. 325-327.

Grigoletti A Jr, Auer CG, Bade JHC. Fungos associados a sementes de erva-mate procedentes de oito municípios do estado do Paraná. Brasília: Embrapa; 1998.

Henning AA. Patologia e tratamento de sementes: noções gerais. Londrina: Embrapa Soja; 2004.

Jaccoud Filho DS, Dabul ANG. Novos métodos de detecção de fungos em sementes florestais. In: Santos ÁF, Parisi JJD, Menten JOM. Patologia de sementes florestais. Colombo: Embrapa Florestas; 2015. p. 69-96.

Kruppa PC, Russomanno OMR. Fungos em plantas medicinais, aromáticas e condimentares - solo e semente. Biológico 2011; 73(1): 33-38.

Lazarotto M, Muniz MFB, Santos AF. Detecção, transmissão, patogenicidade e controle químico de fungos em sementes de paineira (Ceiba speciosa). Summa Phytopathologica 2010; 36(2): 134-139.
Lazarotto M, Muniz MFB, Beltrame R, Santos AF, Maciel CG, Longhi SJ. Sanidade, transmissão via semente e patogenicidade de fungos em sementes de Cedrela fissilis procedentes da região sul do Brasil. Ciência Florestal 2012; 22(3): 493-503.Maccari A. Análise do pré-processamento da erva-mate para chimarrão [thesis]. Campinas: Universidade Estadual de Campinas; 2005.

Machado JC. Patologia de sementes: significado e atribuições. In: Carvalho NM, Nakagawa J. Sementes: ciência, tecnologia e produção. 5th ed. Jaboticabal: Funep; 2012.

Marcos Filho J. Fisiologia de sementes de plantas cultivadas. 2th ed. Londrina: Abrates; 2015.

Mazuchowski JZ. Manual da erva mate (Ilex paraguariensis). Curitiba: EMATER; 1989.

Munsell Color. Munsell soil color charts: with genuine Munsell color chips. v. 1. Grand Rapids: Munsell Color; 2009.

Oliveira E, Maciel CG, Campagnolo K. Qualidade sanitária de sementes de erva-mate. Unoesc \& Ciência 2015; 6(2): 233-240.

Parisi JJD, Santos ÁF. Métodos convencionais de detecção de fungos em sementes. In: Santos ÁF, Parisi JJD, Menten JOM. Patologia de sementes florestais. Colombo: Embrapa Florestas; 2015. p. 49-62.

Poletto I. Nutrição, sombreamento e antagonismo biológico no controle da podridão-de-raízes da erva-mate (Ilex paraguariensis A. St.-Hill) [thesis]. Santa Maria: Universidade Federal de Santa Maria; 2008.

Poletto I, Muniz MFB, Ceconi DE, Poletto T. Aspectos epidemiológicos da podridão-de-raízes da erva-mate (Ilex paraguariensis). Ciência Florestal 2015; 25(2): 281-291.

Poletto I, Muniz MFB, Ceconi DE, Mezzomo R, Rodrigues J. Influência da inoculação de Fusarium spp. e níveis de sombreamento no crescimento e desenvolvimento da erva-mate. Ciência Florestal 2010; 20(3): 513-521.

Poletto I, Muniz MFB, Ceconi DE, Santin D, Weber MN, Blume E. Zoneamento e identificação de Fusarium spp. causadores de podridão de raízes em plantios de erva-mate (Ilex paraguariensis A. St.-Hil.) na região do vale do Taquarí, RS. Ciência Florestal 2006; 16(1): 1-10.

Rego AM. Análise sanitária na produção de sementes de grandes culturas. In: Zambolim L. Sementes: qualidade fitossanitária. Viçosa: UFV; 2005. p. 267-294.

Russel R, Paterson M, Lima N. Molecular biology of food and water borne mycotoxigenic and mycotic fungi. London: CRC Press; 2016.

Sturion JA, Resende MDV. Melhoramento genético de erva-mate. Colombo: Embrapa Florestas; 2010.

Zauza EÂV, Alfenas AC, Mafia RC. Esterilização, preparo de meios de cultura e fatores associados ao cultivo de fitopatógenos. In: Alfenas AC, Mafia RC. Métodos em fitopatologia. Viçosa: Ed. UFV; 2007. p. 23-52. 